\title{
Double diagnosis of coronary artery disease and left ventricular non-compaction - case study
}

Podwójna diagnoza u pacjenta z chorobą niedokrwienną serca i niescaleniem mięśnia sercowego

\author{
Zofia Dzielińska', Joanna Petryka ${ }^{1,2}$, Mariusz Kuśmierczyk², Mirosław Skwarek¹, Marcin Demkow ${ }^{1}$ \\ 1Department of Coronary Artery Disease and Structural Heart Diseases, Institute of Cardiology, Warsaw, Poland \\ 2Magnetic Resonance Unit, Institute of Cardiology, Warsaw, Poland \\ 32Department of Cardiac Surgery and Transplantology, Institute of Cardiology, Warsaw, Poland
}

Postep Kardiol Inter 2012; 8, 4 (30): 329-334

DOI: $10.5114 /$ pwki.2012.31914

\begin{abstract}
We present a rare case of double diagnosis of coronary artery disease and left ventricle non-compaction (LVNC) treated successfully with coronary artery bypass graft operation on the basis of viability assessment by cardiac magnetic resonance (CMR). A 71-year-old patient with a history of previous myocardial infarction of the inferior wall was admitted to our centre with pulmonary oedema following worsening symptoms of heart failure over the previous several days. Echocardiography revealed widely spread regional wall motion abnormalities with decreased left ventricular global function and hypertrabeculations of the inferior and posterior wall suggesting left ventricular non-compaction. Cardiac magnetic resonance confirmed the diagnosis of LVNC and demonstrated preserved viability of all myocardial segments. The patient underwent a successful coronary artery bypass graft operation. In the followup CMR study an improvement in left ventricular systolic function with sustained hypertrabeculation of the myocardium was reported. With the improvement of imaging techniques we are seeing even more cases of LVNC in clinical practice while the ultimate diagnostic criteria have not been established and its management remains a controversy. In the presented case of a 71-year-old man the patient improved greatly after revascularization. The morphology and viability of the myocardium were assessed accurately with CMR, which is a powerful diagnostic tool increasingly often used for everyday clinical decisions.
\end{abstract}

Key words: coronary artery disease, left ventricular non-compaction, cardiac magnetic resonance, myocardial viability

\section{Streszczenie}

Przedstawiono rzadki przypadek jednoczesnego rozpoznania choroby niedokrwiennej serca (coronary artery disease - CAD) i niescalenia mięśnia sercowego (left ventricle non-compaction - LVNC) skutecznie leczonych operacją pomostowania aortalno-wieńcowego (coronary artery bypass graft operation - CABG) na podstawie oceny żywotności miokardium w badaniu rezonansu magnetycznego serca (cardiac magnetic resonance - CMR). Pacjent 71-letni z przebytym zawałem serca ściany dolnej został przyjęty do ośrodka autorów z powodu obrzęku płuc poprzedzonego kilkudniowymi, nasilającymi się objawami niewydolności serca. W badaniu echokardiograficznym stwierdzono rozległe zaburzenia kurczliwości z obniżoną frakcją wyrzutową lewej komory oraz cechy wzmożonego beleczkowania ściany dolnej i tylnej sugerujące LVNC. W badaniu metodą CMR potwierdzono rozpoznanie i uwidoczniono zachowaną żywotność wszystkich segmentów miokardium. Pacjenta poddano operacyjnemu leczeniu rewaskularyzacyjnemu z dobrym efektem. W kolejnym badaniu CMR stwierdzono poprawę czynności skurczowej lewej komory i utrzymujące się wzmożone beleczkowanie mięśnia sercowego. Wraz z rozwojem technik obrazowych zwiększa się liczba diagnozowanych przypadków LVNC w praktyce klinicznej, chociaż dotąd nie powstały jednoznaczne wytyczne dotyczące kryteriów diagnostycznych i leczenia. W przedstawionym przypadku odnotowano istotną poprawę kliniczną po leczeniu rewaskularyzacyjnym. Morfologię i żywotność mięśnia sercowego oceniono za pomocą CMR. Znaczenie tej metody diagnostycznej stale wzrasta w codziennej praktyce klinicznej.

Słowa kluczowe: choroba niedokrwienna serca, niescalenie mięśnia sercowego, rezonans magnetyczny serca, żywotność mięśnia sercowego

Corresponding author/Adres do korespondencji:

Joanna Petryka MD, PhD, Institute of Cardiology, 42 Alpejska St, 04-628 Warsaw, Poland, tel.: +48 5042734 09,

e-mail: joannapetryka@hotmail.com

Praca wptynęła: 7.08.2012, przyjęta do druku: 30.10.2012. 


\section{Case report}

A 71-year-old man with a history of ischaemic heart disease and inferior myocardial infarction treated medically in 1989 was admitted to the Institute of Cardiology due to pulmonary oedema preceded by a short history of worsening symptoms of heart failure. ECG showed sinus rhythm with QS in leads III and aVF, lack of R wave progression in anterior leads and reversal of $T$ waves in leads I-II and V4V5. Levels of markers of myocardial injury were within the reference range. Echocardiographic examination demonstrated impaired left ventricular systolic function with ejection fraction of $30 \%$, regional wall motion abnormalities with akinesis of the inferior and septal apical segments and hypokinesis of the lateral wall. There was also notably increased trabeculation of the lateral and posterior wall suggesting left ventricular non-compaction. Coronary angiography disclosed occlusion of all three coronary arteries: left anterior descending (LAD) artery and circumflex (CX) artery of the left coronary artery and right coronary artery. The further diagnostic course included cardiovascular magnetic resonance (CMR) targeted at myocardial viability assessment before qualification for revascularization. The examination confirmed the presence of left ventricular non-compaction with an end-diastolic ratio of non-compacted to compacted myocardium $>2.3$ (Fig. 1). There were also subendocardial areas of delayed enhancement not exceeding $25 \%$ of the left ventricular wall thickness located in the anterior and antero-septal left ventricular segments (Fig. 2). Delayed enhancement was not present in the trabeculae, which would have been a sign of gadolinium-based contrast medium retention in that area. Because of the preserved viability of all myocardial segments with coexisting regional systolic dysfunction and globally impaired left ventricular ejection fraction the patient was qualified for coronary artery bypass grafting (CABG). The surgical revascularization was only partial and consisted of left internal mammary artery implantation to the left anterior descending artery. This was determined by an increased peri-operative risk related to the markedly impaired left ventricular systolic function. Cardiovascular magnetic resonance was repeated three months after the procedure. In the meantime the patient did not complain of angina, he had a good exercise tolerance (NYHA I) and did not have any cardiovascular adverse events. Volumetric and functional left ventricular parameters before and after the CABG are presented in Table I. There was a marked improvement of the left ventricular systolic function with a decrease of end-systolic volume and an increase of ejection fraction. Improvement of contractility after revascularization is demonstrated in Figure 3 presenting end-systolic and end-diastolic frames in short axis and 4-chamber view.

\section{Discussion}

We present an interesting case of a patient with dual diagnosis consisting of ischaemic heart disease and left ventricular non-compaction (LVNC). Ischaemic heart disease is a major cause of death in the developed countries
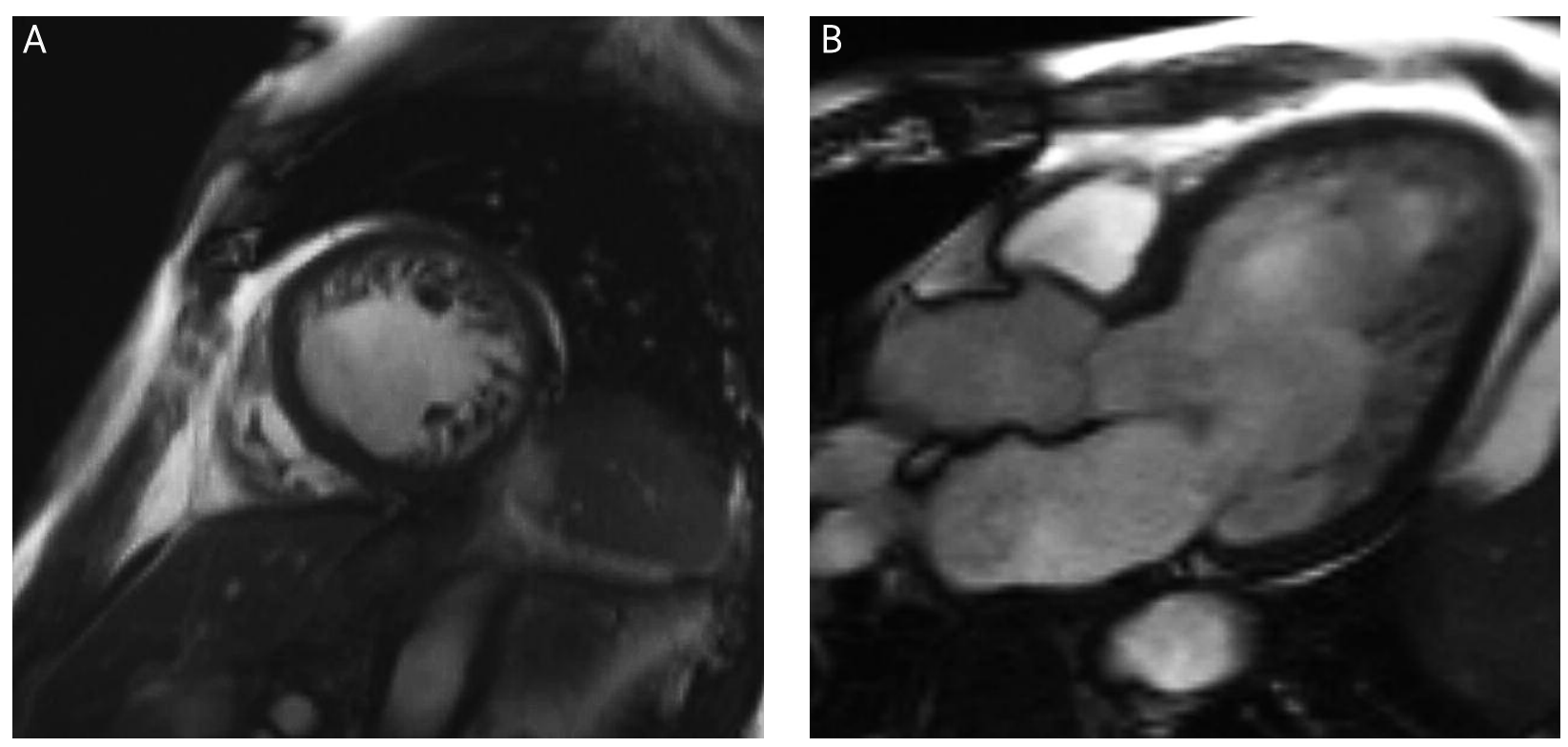

Fig. 1. Prominent trabeculations in the antero-lateral and infero-lateral segments with a ratio of non-compacted to compacted myocardium of > 2.3. A - Short axis view, NC/C 2.4, B - three-chamber view NC/C, 3.2

Ryc. 1. Wzmożone beleczkowanie w segmentach przednio-bocznych i dolno-bocznych ze wskaźnikiem niescalonego do scalonego mięśnia sercowego > 2,3. A - Projekcja dwujamowa w osi krótkiej, NC/C 2,4, B - projekcja trzyjamowa, NC/C 3,2 

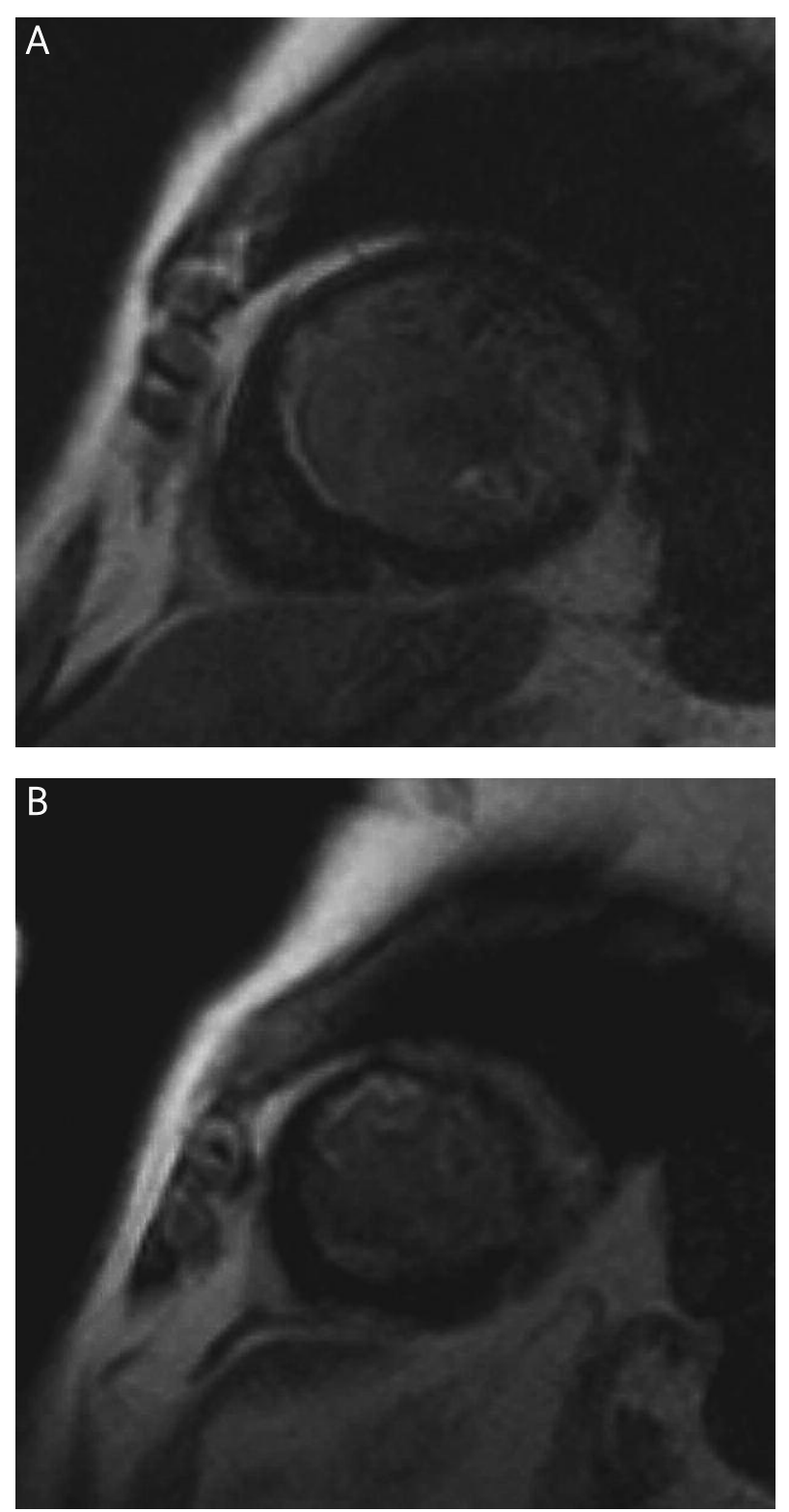

and is commonly diagnosed by physicians of any specialty. In contrast, the problem of left ventricular non-compaction is relatively not widespread as the frequency of this disease is estimated at below $1: 50000$. There are no large multicenter studies on patients with left ventricular noncompaction in the literature. The first case report of LVNC was published in 1975 [1]. The diagnostic criteria have been a matter of controversy since then and currently there is still no universally accepted definition of LVNC. Echocardiographic criteria are based on the presence of at least 2-fold thicker layer of non-compacted than compacted myocardium in the end-systolic phase. However, most authors of reports on non-compaction using magnetic resonance follow the diagnostic criterion of non-compacted to compacted myocardial thickness ratio $>2.3$ measured in end-diastole. This cut-off value was related to satisfactory diagnostic accuracy in the detection of LVNC in terms

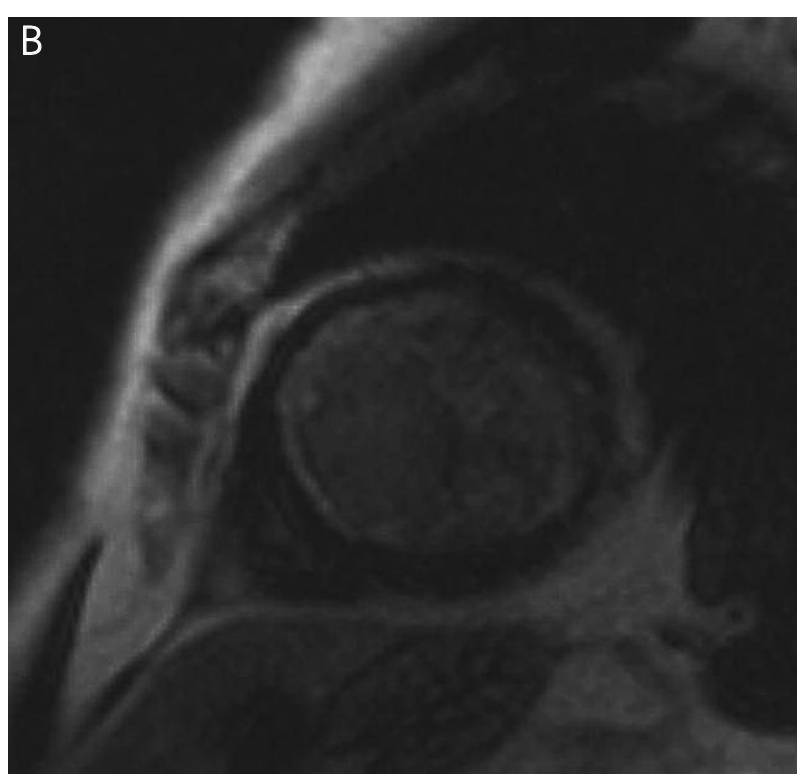

Fig. 2. Late gadolinium enhancement up to $25 \%$ of the myocardial wall in basal anterior and anteroseptal segments (A), mid anterior and antero-septal segments (B) and apical anterior segment (C) Ryc. 2. Późne wzmocnienie pokontrastowe obejmujace do 25\% grubości mięśnia lewej komory $w$ segmentach podstawnych przednim i przednio-przegrodowym (A), środkowych przednim i przednio-przegrodowym (B) oraz koniuszkowym segmencie przednim (C)

Table I. Volumetric and functional parameters prior to and after CABG operation

Tabela 1. Parametry objętościowe i czynnościowe przed operacją i po operacji pomostowania aortalno-wieńcowego

\begin{tabular}{lcc} 
Parameters of left ventricle & $\begin{array}{c}\text { Before } \\
\text { procedure }\end{array}$ & $\begin{array}{c}\text { After } \\
\text { procedure }\end{array}$ \\
\hline End-diastolic volume $[\mathrm{ml}]$ & 310 & 255 \\
\hline End-systolic volume $[\mathrm{ml}]$ & 230 & 135 \\
\hline Stroke volume $[\mathrm{ml}]$ & 80 & 120 \\
\hline Ejection fraction $[\%]$ & 26 & 47 \\
\hline Weight $[\mathrm{g}]$ & 116 & 117
\end{tabular}

of sensitivity (86\%) and specificity (99\%) [2]. The advantage of cardiovascular magnetic resonance in comparison to echocardiography is its possibility of imaging in any cho- 

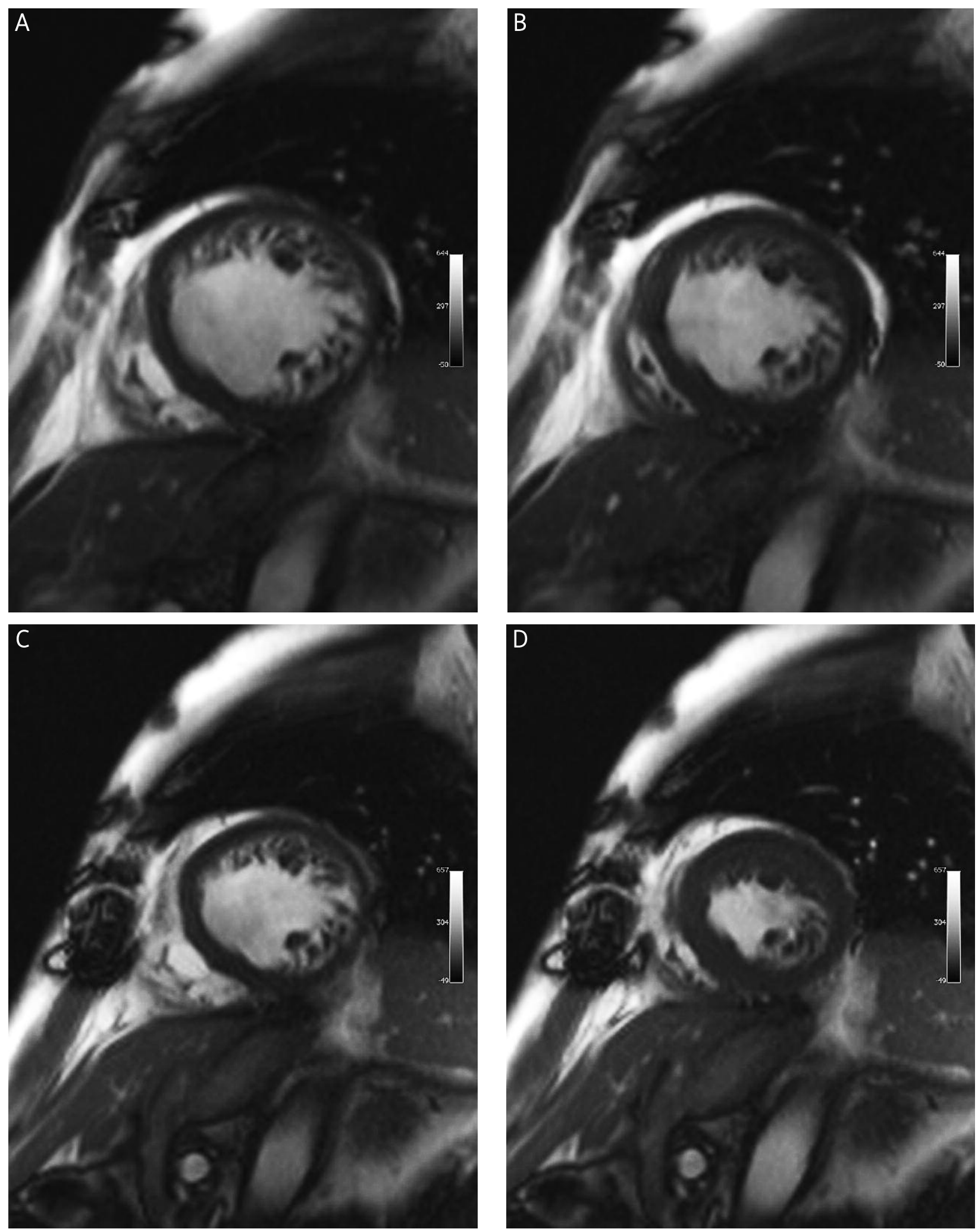

Fig. 3. Baseline and follow-up MRI cine images demonstrating improvement in regional wall motion. A-Mid short axis diastole pre-op, B - systole pre-op, C - diastole post-op, D - systole post-op and four-chamber view Ryc. 3. Kinematograficzne obrazy rezonansu magnetycznego ilustrujące poprawę kurczliwości przed leczeniem operacyjnym i po nim. A - Faza końcoworozkurczowa w osi krótkiej przed operacją, B - faza końcowoskurczowa w osi krótkiej przed operacja, C - faza końcoworozkurczowa w osi krótkiej po operacji, D - faza końcowoskurczowa w osi krótkiej po operacji 

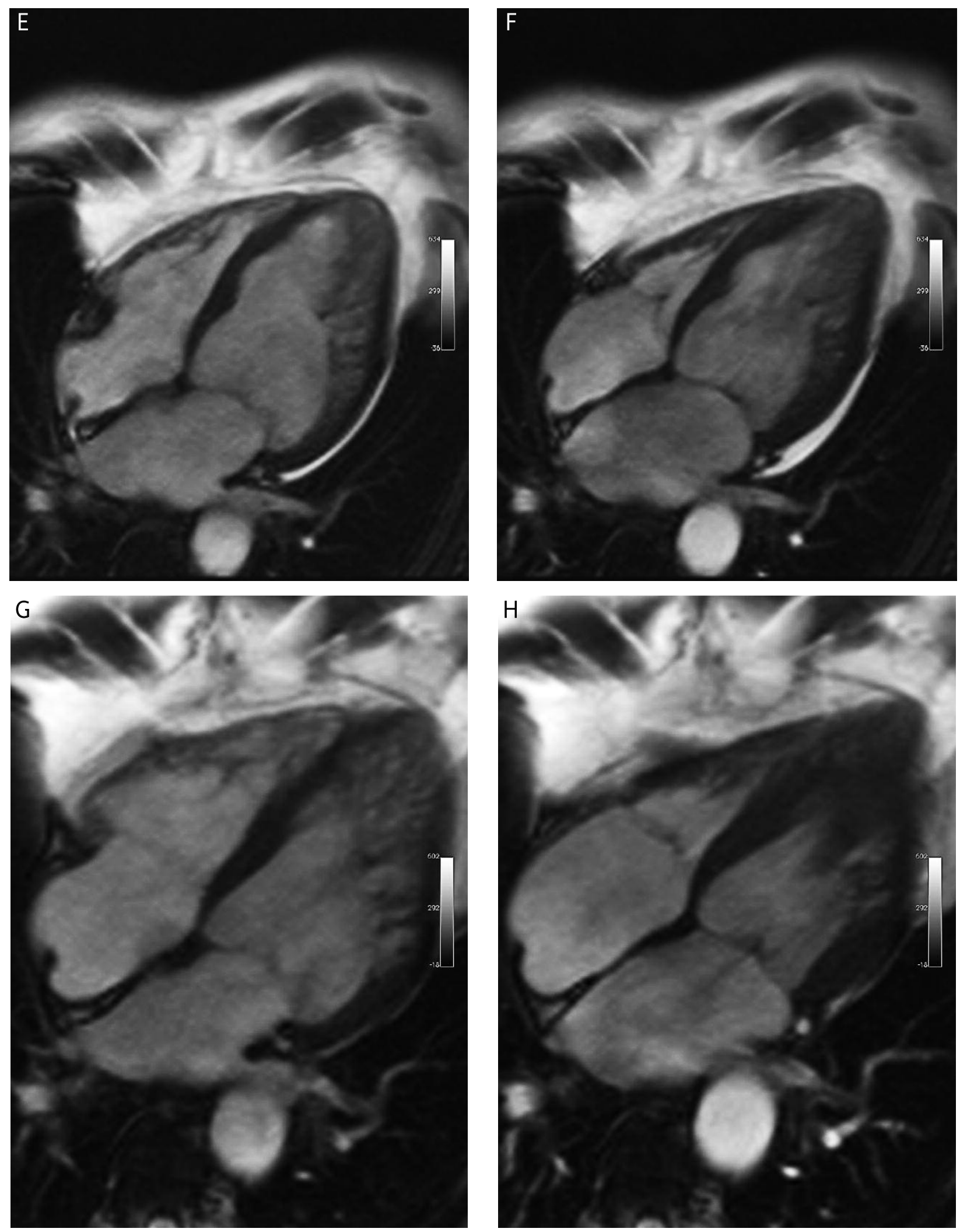

Fig. 3. Cont. E - diastole pre-op, $\mathrm{F}$ - systole pre-op, $\mathrm{G}$ - diastole post-op, $\mathrm{H}$ - systole post-op

Ryc. 3. cd. E-faza końcoworozkurczowa w projekcji czterojamowej przed operacja, $F$-faza końcowoskurczowa w projekcji czterojamowej przed operacja, $\mathbf{G}$ - faza końcoworozkurczowa w projekcji czterojamowej po operacji, $H$-faza końcowoskurczowa w projekcji czterojamowej po operacji 
sen plane and better visualization of anterior, antero-lateral and infero-lateral segments as well as better spatial resolution of the technique allowing better discrimination between compacted and non-compacted layers [3]. However, there are no documents on the prognostic value of the extent of hypertrabeculation or the value of noncompacted to compacted (NC/C) ratio. Importantly, cardiovascular magnetic resonance can depict the areas of delayed enhancement not only in the segments with compacted myocardium, but also in myocardium with increased NC/C ratio [4]. In the presented case the qualification for revascularization was based on the assessment of myocardial viability in the presence of occlusion of all three coronary arteries and impaired left ventricular ejection fraction. Despite akinesis of the inferior and septal apical segments on the echocardiographic examination there were no signs of postinfarction scar on CMR in that localization. The presence of delayed enhancement encompassing up to $25 \%$ of the myocardial thickness only in the antero-septal wall suggested that there is a high probability that systolic performance of dysfunctional segments will improve after successful revascularization [5].

In the presented case, incomplete revascularization of the advanced ischaemic heart disease led to expected improvement of the left ventricular myocardial contractility without significant influence on the degree of myocardial non-compaction.

\section{References}

1. Chin TK, Perloff JK, Williams RG, et al. Isolated noncompaction of left ventricular myocardium. A study of eight cases' Circulation 1990; 82: 507-513.

2. Petersen SE, Selvanayagam JB, Wiesmann F, et al. Left ventricular non-compaction: insights from cardiovascular magnetic resonance imaging. J Am Coll Cardiol 2005; 46: 101-105.

3. Thuny F, Jacquier A, Jop B, et al. Assessment of left ventricular non-compaction in adults: Side-by-side comparison of cardiac magnetic resonance imaging with echocardiography. Arch Cardiovasc Dis 2010; 103: 150-159.

4. Dodd JD, Holmvang G, Hoffmann U, et al. Quantification of left ventricular noncompaction and trabecular delayed hyperenhancement with cardiac MRI: correlation with clinical severity AJR 2007; 189: 974-980.

5. Kim RJ, Shah DJ. Fundamental concepts in myocardial viability assessment revisited: when knowing how much is "alive" is not enough. Heart 2004; 90: 137-140. 